\title{
Waarheid en betekenisgelaagdheid ${ }^{1}$
}

D A Du Toit

(Universiteit van Stellenbosch)

\section{ABSTRACT}

\section{Truth and layers of meaning}

An evaluation of an individual's contribution towards theology needs to be placed against the backdrop of the story of faith and theology. In this case it would be the story of religious and theological truth, taking it up in the early Christian Church with the example of the descensus. That showed a plurality of fundamental expressions of faith, as well as a plurality of the forms in which truth is expressed and layered reality of meaning which progressively became unveiled in history. Although this diversity and process was halted by the modern rationalistic intermezzo of the Enlightenment which reduced it to logical, rational and verifiable eternal truths, it gradually reappears in various forms of post-modern thought. It is part of the exciting story of faith and theology in our own time.

\section{INLEIDING}

Die Kuratorium van die Ned. Geref. Kerk aan die Fakulteit Teologie van Pretoria moet van harte gelukgewens word met die instelling van die Johan Heyns-gedenklesing. Vir my is dit 'n baie groot eer en voorreg om op hierdie wyse daaraan deel te hê. Die meriete vir die instelling van so ' $n$ gedenklesing is sonder meer duidelik en setel in die persoon en werk van 'n hoogs gewaardeerde kollega. Waar ' $n$ mens in ' $n$ artikel soos hierdie meer oorsigtelik en bevatlik na enkele aspekte van die storie van geloof en teologie wil kyk, kan jy nie anders nie as om tog te dink aan wat Johan Heyns nog sou kon bygedra het, veral met sy passie vir die teologie, sy energie en werkvermoë, sy belesenheid en verbluffende vermoë om altyd weer tyd te vind vir besinning en publikasie. My bydrae is ' $n$ baie beskeie poging tot ' $\mathrm{n}$ huldeblyk aan hierdie vriend en kollega, aan die baie aangename herinnering aan ons kollegaskap en die jare saam (veral

1 Hierdie artikel het oorspronklik gedien as eerste Johan Heynsgedenklesing wat op 23 Mei 2005 gelewer is in die Fakulteit Teologie van die Universiteit van Pretoria. Die outeur is emeritus professor in die Sistematiese Teologie aan die Universiteit van Stellenbosch. 
die sewentigs en tagtigs van die vorige eeu) in die stryd om kerk en politiek, AKLAS, Kerk en Samelewing, asook in academia.

\section{DUIDELIKHEID, WETE EN KONTROLE}

Die storie van geloof en teologie, en dus ook van kerkwees, was nog altyd intiem verweef met die kwessie van waarheid en daarom ook met die aard en verskeidenheid van religieuse uitsprake. Die vertel van dié storie word ' $n$ speurtog na die struktuur en modelle van teologisering en teologiese uitleg, die hermeneutiek van historiese interpretasie en die bronne en grondvorme van geloofsuitsprake.

Die Heidelbergse Kategismus (vraag en antwoord 21) beskryf ' $n$ ware (dit gaan dus om die waarheid) geloof as ' $n$ vasstaande kennis en ' $n$ vaste vertroue wat onderskeidelik slaan op die openbaring in die Skrif en die verlossende werk van die drie-enige God. In die lig van die huidige debat rondom die teologie en die postmodernisme sou 'n mens hierdie uitspraak van 1563 as 'n merkwaardige formulering kon beskryf. Daarmee word die waarheid nie alleen op die kennis betrek nie, maar ook op die vertroue. Die voorkoms van soortgelyke begrippepare in die storie van die Christendom is welbekend: rede en geloof, wetenskap en godsdiens, duidelikheid en wete, aantoonbaarheid of aanvaarding, verstaan en glo, verstaan en weet, rede en intuïsie, dogma en liturgie en selfs Grieks en Hebreeus. Die meestal eksklusiewe situering van die waarheid aan die een óf ander kant was telkens van beslissende betekenis vir geloof, teologie én kerk. Veral ook omdat dit verstrengel geraak het met die immer en universele strewe van die mens na beheer, kontrole en mag.

' $n$ Mens sou naamlik die geskiedenis van die mensheid kon beskryf as die geskiedenis van die mens se strewe om te oorleef. Oorlewing het afgehang van die mens se vermoë om beheer of kontrole te verkry oor die faktore wat daardie oorlewing bedreig het. Teenoor die natuur se bedreiging het die mens ontwikkel in ' $\mathrm{n}$ homooecumenicus en technologicus, teenoor die bedreiging van ander mense in ' $n$ homo politicus, en teenoor die bedreiging van God/gode in ' $n$ homo religionis. ' $n$ Rewolusie teen God/gode, hetsy in die paleis óf die tuin, was teen die goddelike almag onhaalbaar. Gedwonge om God/gode te dien, sou juis dit, naamlik die godsdiens, die middel word om ' $n$ sekere kontrole oor God/gode te verkry. Die geskiedenis toon duidelik hoedat die kontrolemeganismes van tegnologie, ekonomie, politiek en godsdiens telkens die oer-instink van die mens tot mag en kontrole sou dien. 


\section{TEOLOGIESE EN ANTROPOLOGIESE GRONDVOR- ME VAN RELIGIEUSE UITSPRAKE}

Wat die godsdiens betref was die vroegste vorme van godsdienstige uitsprake oorwegend oorgelewerde rituele: danse, sang, mimiek, magiese voorstellings, geykte besweringsrituele ens, ondersteun deur oorsprongsverhale, mites en stories. Dit is opmerklik hoe sprekend en belangrik hierdie rituele nog in die Ou Testament is, en op watter wyse dit in ' $n$ mindere of meerdere mate in die onderskeie Christelike tradisies voortleef. Rituele en liturgie behoort tot die oervorme van godsdienstige spreke - daarsonder sou "die waarheid" onvolledig wees.

Vanweë die kritiese vormingsjare van die jeugdige Christendom in die Grieks-Hellenistiese wêreld, sou die redelike of rasionele uitbouing van hulle geloof mettertyd ' $n$ besondere sterk klem ontvang, met name in die Westerse deel van die kerk, soms tot so ' $n$ mate dat liturgie en ritueel byna tot volledige swye gebring is. Vir minstens die eerste \pm 150 -200 jaar $\mathrm{n} C$ was die grondvorm van religieuse uitsprake egter nog nie rasioneel-dogmaties van aard nie. Die sentrale grondvorm was die gebed, 'n direkte en persoonlike dimensie van spreke met die fasette van bieg, bely, dank, aanbid en lofprys - 'n doksologiese diens aan God (latreia). Tweedens was daar die grondvorm van getuienis, met al die fasette van verkondiging, sending, kategese, paranese, oorlewering, onderrig en belydenis dikwels in geykte formules.

Edmund Schlink (1961:24-80) oordeel dat die inhoud van die evangelie hoofsaaklik in veral vier grondvorme van religieuse uitsprake voorkom, naamlik gebed, getuienis, doksologie en leer. Hierdie uitsprake of geloofsantwoorde word dan op 'n unieke wyse in die geloofsbelydenis gekonsentreer sodat dit soms saamval. In die lees daarvan moet nietemin die oorspronklike vorm ontsyfer word, anders kan dit maklik gebeur dat die verskeidenheid verlore gaan en al die uitsprake dan in terme van slegs één daarvan verstaan word. Die gevolg is onvermydelik ' $n$ morfologiese en inhoudelike skeeftrekking en verarming. Die Apostolicum, byvoorbeeld, as oorspronklik die belydenisakte aangaande die inhoud van die evangelie mét die verskillende religieuse grondvorme daarin vervat, is dikwels later verarm tot ' $\mathrm{n}$ leer óór die belydenis. Die grondvorm van die getuienis (gesprek, verhaal, gelykenis, onderrig, vertelling) sou op soortgelyke wyse verskraal kan word tot polemiek of apologetiek. Die grondvorm wat egter in die geskiedenis die meeste verarm en uitge- 
hol is, is die doksologie. Hierdie uitsprake, in die vorm van syns-, wesens- en eienskapsuitsprake waarmee God aanbid, geloof en geprys word, is dikwels gestol, gevries en gefossileer tot dogmatiese of metafisiese uitsprake óór God.

Daarbenewens is daar ook algemene antropologiese grondvorme van uitsprake wat as blywende kennismatige, logiese, wêreldbeskoulike, sosiologiese, linguïstiese en ander hebbelikhede meespeel in die formele raamwerk en inhoude van religieuse uitdrukkings. Vereensydiging en vertekening kan ook hier plaasvind, byvoorbeeld wanneer ' $n$ veelheid van uitsprake in een grondvorm, byvoorbeeld die logies-rasionele geforseer word. 'n Belangrike faktor wat hier bykom is die feit dat ' $n$ bepaalde grondvorm soos die logies rasionele gebruik kan word om ' $n$ sekere mag of kontrole te bekom in 'n bepaalde opset.

Die belangrike punt is egter dat die veelheid van grondvorme van religieuse uitsprake verskillende gestaltes van die waarheid meebring. Dit hang op sy beurt saam met die verskynsel dat benewens die (sê maar) horisontale verskeidenheid van gestaltes die waarheid ook ' $n$ (sê maar) vertikale gelaagdheid kry wat op verskillende tye ontsluit word. Alleen al hierdie opset maak die "openheid" en "onafgehandeldheid" van enige waarheid duidelik sonder om hoegenaamd die geldigheid daarvan te ontken. Die interpretasiegeskiedenis van die neerdaling ter helle is ' $\mathrm{n}$ baie goeie voorbeeld (Du Toit 1971). Toe ek 35 jaar gelede hierdie stuk navorsing voltooi het, was ek hoegenaamd nie bewus van die volle implikasies van sommige resultate nie - was daar ook 'n waarheidsgelaagdheid ter sprake wat eers met tyd onthul sou word?

Op daardie stadium was die kerklike belydenisskrifte sterk in die gedrang en die vraag of die Heidelbergse Kategismus korrek was in sy uitleg van die descensus was maar één van die vrae. Maar veral: wat maak die descensus in die Apostolicum as die enigste artikel wat nie op Skrifgronde gebaseer is nie? Dit was duidelik dat die vroegste oorsprong en ontwikkeling daarvan in detail nageloop sou moes word.

Voorbeelde van sulke neerdalings kom by feitlik alle vroeë godsdienste en kulture voor en weerspieël die mens se nuuskierigheid oor die dood, verlange na 'n afgestorwene ens, maar veral die universele worsteling met die dood as lewenseinde wat effektief alle mag, kontrole en beheer beëindig. Dit vind neerslag in dramatiese-, 
epiese-, digterlike- of himniese stof met die yking van almags- en patos-formules wat ook kultuurgrense oorsteek (Du Toit 1971:46v). Ten spyte van die oorvloedige voorkoms daarvan reg rondom Israel word dit nêrens in die Ou Testament opgeneem nie (Du Toit 1971:63v). En ten spyte van die sterk opbloei daarvan in die Joodse apokaliptiek met veelvuldige doderyksdetail en skouspelagtige beskrywings word dit ook nêrens in die Nuwe Testament opgeneem nie (Du Toit 1971:85v). Die gebruik van 1 Petrus 3:19 en 4:6 in hierdie verband sou eers eeue later opduik - teksgedeeltes wat tans deur min kenners as van toepassing op die descensus beskou word. Die Bybel is klaarblyklik nie geïnteresseerd in die mens se eie pogings om self ' $n$ finale kontrole of mag oor die dood te verkry nie.

Die begeerte daartoe is egter altyd en universeel, wat ook verklaar waarom die apokriewe met doderyksdetail en neerdalings in die vroeë Christendom so wyd bekend en hoogs gewild was. Hieronder val 1 Henog, die Baruch-apokalips, 4 Esra, die pastor van Hermas, die Openbaring van Petrus, die Petrusevangelie, Odes van Salomo, Oracula Sibyllina e.a. Hierdie geskrifte toon sterk Oosterse invloede van spreke en denke, naamlik ' $n$ eenheidsdenke en ' $n$ funksioneelgerigte voorstellingswyse as uitdrukking van eksistensiële en religieuse inhoude in poëties-profetiese taal wat gemaklik logiese en rasionele teenstrydighede (nl volgens Westerse- of Griekse denke) langs mekaar kan behou. Daarteenoor kom die descensus, in navolging van die Bybel, nêrens in formele of kerklike geskrifte, of in enige credomateriaal of "leerstellige" materiaal voor nie (vgl die werk van Ignatius, Polycarpus, Justinus, Irenaeus en die Epistula Apostolorum). Die heelwat later "teologiese" verwerking daarvan deur Clemens en Origenes het sulke ongelukkige gevolge gehad vir die Bybelse betekenis van die evangelieverkondiging, kruis en opstanding dat dit nie navolging gevind het nie (Clemens en Origenes was die eerstes wat die Petrus-tekste gebruik het) (Du Toit 1971:131v). Klaarblyklik besit die descensus ' $n$ onvertaalbaarheid in Westerse dogmatiek.

Die grondvorme waaruit dit voorkom is deurgaans van liturgies-himniese, retoriese of plegtige homiliestyl met gaandeweg min of meer vaste liturgiese of doksologiese formules (Altaner \& Stuiber 1966:89 noem dit die "asianische Kunstprosa”). Die bronne is ' $\mathrm{n}$ groot verskeidenheid van preekstof, verse, himnes en ander digterlike stukke tot mities-getinte en dramatiese monografiese roman-literatuur wat gerig is op effektiewe belewing en religieuse 
patos. Dit is deurgaans fantasieryk, skouspelagtig, visioenêr en sou vir meer as ' $n$ duisend jaar in hierdie vorm in die Christendom voortbestaan, veral in die uiteindelike apokaliptiese tekening van ' $n$ geweldige stryd en oorlogsgeweld met die grootse oorwinning van Christus in die onderwêreld.

Dit was Gustaf Aulen wat in sy intussen klassiek geworde "Christus Victor" (Aulén 1969) op die betekenis hiervan gewys het. Teenoor die veel latere idees van Anselmus en Abelardus noem hy dit die "klasieke" opvatting van die versoening, die eintlike tipies Christelike gesigspunt as ' $\mathrm{n}$ dramatiese voorstelling wat tot in die Middeleeue aanvaar is, waar dit nie gaan om óf God se versoening óf die mens se individuele versoening nie, maar om die kosmiese redding van die wêreld in ' $\mathrm{n}$ grootse oorwinning oor die magte van sonde en dood. Hy is oortuig dat dit ook die agtergrond vorm van die Nuwe Testament (Aulén 1969:4v), maar veral ook dat dit die model was wat deur Martin Luther gebruik was (Aulén 1969:14,101v, 143).

Klaarblyklik val die descensus ook geheel buite die spanningsveld van ortodoksie-kettery. Die ontwikkeling van die descensusvoorstellings toon ' $\mathrm{n}$ bykans eindelose stroom van variasies, weglatings, byvoegings en selfs verrassings, soos die descensus apostolorum of neerdaling van die apostels, en selfs op ' $\mathrm{n}$ keer ook van Maria - dit alles klaarblyklik sonder die geringste vrees vir ' $n$ aanklag van kettery. Dit is merkwaardig in ' $n$ tyd toe ' $n$ enkele i die verskil tussen ortodoks en ketters kon beteken! Almal betrokke het klaarblyklik aanvaar dat dit nie 'n kwessie van leer of dogma was nie. Wanneer dit in 359 (Du Toit 1971:195v) bykans volkome geruisloos in die credo opgeneem word (die vierde formule van Sirmium) bly dit ewe geruisloos daar. Die eerste kommentaar daarop as deel van die leer (Rufinus van Aquileja) vyftig jaar later verklaar dit eenvoudig net as ' $\mathrm{n}$ sinoniem vir sterf. Daar kan geen dogmatologiese leerstellige, polemiese of apologetiese gronde vir die opname aangetoon word nie. Dit het op geen moment klaarblyklik enige geloofskritiese rol gespeel nie en figureer glad nie in die debat en argumente van die groot stryd van daardie tyd nie, te wete. die Christologiese en trinitariese stryd tussen die Oosterse en Westerse dele van die kerk. Dit word aanvaar dat Sirmium 359, wat wesenlik ' $n$ versoeningspoging in die stryd was, enige kontensieuse saak sou vermy, maar juis die invoeging van ' $n$ samebindende en versoenende artikel sou aanvaar. Die descensus was juis so 'n artikel omdat dit beide in die Ooste én die Weste 'n baie bekende, geliefde en alge- 
meen aanvaarde stuk geloofsbesit was wat totaal buite die dogmatiese twiste gestaan het.

Maar wat het dit beteken? Die ontwikkelingsproses wat die descensus in die vroeë eeue van die Christendom deurgemaak het toon ' $n$ gelaagdheid van betekenis (Du Toit 1971:114v). Van die direkte en eenvoudige betekenis van 'n sinoniem vir sterwe of dood, dit wil sê dat Jesus in die doderyk was, ontwikkel dit tot 'n polemiese aanduiding van die egtheid van sy dood teenoor dosetisme en gnostisisme. Dit is daarom ook ' $n$ aanduiding van die egtheid en waarheid van die opstanding. Die betekenislae sou juis in verband met Jesus se heilswerk gesien word. Eerstens bied dit ' $n$ verklaring van die lot van die Ou Testamentiese vromes in die doderyk. Hier vind ons ook mettertyd 'n ontwikkeling: aanvanklik is dit net die blote aankondiging van die feit dat die heil gekom het. Dit word later meer volledig prediking (soos tydens Jesus se aardse lewe). Dit neem egter ' $n$ langer tyd voor dit ontwikkel in heils- en bekeringsprediking, wat later selfs die doop sou insluit. Dit gedagte van die bevryding van die gelowiges in die doderyk was eweneens aanvanklik slegs die aankondiging van hierdie (eskatologiese) vryheid, maar word mettertyd ' $n$ werklike bevryding uit die doderyk. Daarmee saam ontwikkel ook die strydmotief (aanvanklik geweldloos) maar uiteindelik ' $n$ volskaalse oorlog tussen engele en duiwels, waarmee (veral in die vierde eeu) die oorwinningsmotief skouspelagtige vorm gegee word. Jesus neem die dood op hom om dit as't ware van binne af oop te breek. Die kosmiese omvang van Jesus se werk word ook so geteken: nie alleen die hemel en die aarde nie, maar ook die onderwêreld val onder Christus se heerskappy. So word die descensus 'n eskatologiese doksologie wat die hele kosmos, alle gelowiges en alle finale lewensvrae insluit.

Te midde van al hierdie ontwikkelinge by die leerstellige betekenis daarvan deurgaans slegs die sobere feit dat Jesus gesterf het. Hier is dit sy opstanding (en nie die descensus nie) wat die teken van sy oorwinning is (1 Kor 15). Daarmee is die gelaagdheid en veelvormigheid van betekenis en waarheid duidelik, direk in verband met die verskeidenheid van grondvorme van religieuse uitsprake.

Martin Luther is ' $n$ treffende bevestiging hiervan. Hoewel hy lewenslank onseker was hoe om die descensus dogmaties te hanteer, kon hy in die Paaspreek van Torgau die neerdaling beskryf in dieselfde fantasieryke skouspelagtigheid van die ou tradisie: die groot stem wat uitroep, die poorte wat verkrummel en Jesus wat met 
die vaandel in die onderwêreld inmarsjeer, soos ons by Aulén gesien het. Toe hy spoedig daarna gevra is of dit nou alles werklik só gebeur het was sy antwoord "das weis ich warlich nicht" - dit was nie dogmaties bedoel nie. Wel was dit duidelik bedoel as (narratiewe) waarheid om "dem groben Volk kindlich und einfältiglich" die grootsheid en betekenis, die waarheid, van Jesus se oorwinning duidelik te maak. In dogmatiese taal, sê Luther, het Jesus nêrens heen afgedaal nie. Die waarheidsgehalte van beide bly behoue (Vogelsang: Luthers Torgauer Predigt, aangehaal by Du Toit 1971: $17 \mathrm{v})$. Die waarheid is méér as net die logies-rasionele vorm daarvan. Laasgenoemde kan selfs die waarheid verydel (vgl Natan se storie aan Dawid, 2 Sam 12, en Jesus se gelykenisse).

\section{DIE AUFKLÄRUNG EN MODERNITEIT}

Die Aufkläring sou hierin ' $\mathrm{n}$ ingrypende verandering aanbring. Die begin daarvan word meestal verbind met die Cartesiaanse "Cogito ergo sum”, dit wil sê met die radikale metodologiese twyfel as die beginpunt van alle kennis en waarheid. Hierdie rasionalisme word later aangedui as die tydvak van die modernisme of moderniteit, toe alle wetenskappe, ook die teologie, dit sou aanvaar as die korrekte. Ten spyte van Calvyn (Deus dixit) en Luther (theologia crucis) het die rasionalistiese metode vroeg reeds beide tradisies oorheers. Dit sou al moeiliker word om nog iets te begryp van die pre-moderne waarheidsbegrip teenoor die geweldige pretensie en magsgreep van die rasionalisme. Dit is egter foutief om te redeneer dat die modernisme eensklaps die rede ontdek het. In die pre-moderne tyd was mense deeglik bewus daarvan. Gregorius Nazianzus (vierde eeu) kla juis nà een van sy orasies oor sommige van sy teenstanders wat dink alles in die Christelike geloof is bloot ' $n$ kwessie van logies-rasionele deduksie.

Daarvolgens is die waarheid absoluut en ewig, buite die tyd, onveranderlik en toeganklik slegs vir die rede van die outonome denkende subjek. Dit trek 'n streep deur twee fundamentele komponente van die historiese Christelike geloof en waarheidsbeskouing, naamlik eerstens die storie as die éérste roete tot die waarheid (nou word dit gediskrediteer as fiksie en nie as empiries-wetenskaplik waar nie) en tweedens die moederbedding en draer van die narratief en tradisie, te wete die gemeenskap van gelowiges (wat vervang word met die denkende individuele subjek). Die Skrif word benader met 'n eksaktheidseis (Alister McGrath: "military precision", soos aangehaal by Green 2003:18), wat geen ruimte laat vir verskille, 
gelaagdheids-betekenisse, waarheidsgestaltes, paradokse of misterie nie. Daarmee word die realistiese Bybelse narratief geheel misken in wat Hans Frei “The Eclipse of Biblical Narrative” noem as 'n titel van 'n boek van hom (Frei 1974:1994). Dit, naamlik die Bybel, word ' $n$ naslaanwerk en referensiepoel vir dogmaties-rasionalisties stellings aangaande die absolute waarheid. Hierdie metode sou byna onbeperkte mag en kontrole in die hand gee. Kevin Vanhoozer skryf: "Modern thought was characterized by a drive for certitude, universality and perhaps, above all, mastery" (Vanhoozer 2003:8), 'n "allcompassing mastery of reality" waarvoor jy dan ook spoedig ' $n$ "master's degree" ontvang omdat jy deel in die moderne metanarratief of "master story". Die universele waarheidseise is egter eenvoudig maskers vir die ideologie van wil tot mag.

So ontstaan die illusie dat menslike beperktheid oorkom word in die daarstel van absolute waarhede wat as't ware ' $n$ "God's-eye point of view" is. Juis dit gee omvattende mag en kontrole, soveel so dat die een element van geloof, naamlik vertroue, volledig deur die kennis oorbodig gemaak word.

Die evangelie word gelees in terme van ' $\mathrm{n}$ epifaniemodel waardeur God buite die tyd geplaas word en individue uit hierdie wêreld weggeroep word "to contemplate the eternal thoughts of reason" (Moltmann 1993:49) agter die evangelie en om dit dan kognitief te aanvaar. Die kerk word by uitstek die bewaker van leerstellige suiwerheid, dit wil sê absolute waarhede - in 'n sekere sin die historiese hoogtepunt van mag en kontrole.

\section{ETIESE EKSKURS I}

Met hierdie ontwikkeling is die eerste faset (en vir dié tyd die enigste) van teologies-etiese aktiwiteit vasgelê. In 'n rasionele wetenskapsdiskoers word waarhede teoreties geïdentifiseer en wat die etiek betref sou hoogstens, op dieselfde wyse en in dieselfde diskoers, bepaalde waardes en norme aangedui kon word. Daar was weinig appèl op die gewone lewe. Die in die lewe en narratief gesitueerde huistafels van morele optrede in die premoderne tyd is as onwetenskaplik verwerp: die "eclipse of biblical narrative" was ook die "eclipse of narrative ethics". In academia het dit 'n ivoortoring geword, 'n geïsoleerde wetenskapsbedryf wat daarom juis ' $n$ tydverdryf geword het tot nog in die twintigste eeu waar geleerdes vir mekaar geleerde artikels in wetenskaplike tydskrifte skryf. Parallel hiermee het daar ' $n$ depresiasie of afskaling van die rol van 
die Skrif, belydenisskrifte en die Heilige Gees plaasgevind. Die logos van die moderniteit het die Bybelse theos vervang (Tracey 1994:41).

\section{DIE OORGANG}

Die era van absolute tydlose waarhede het, agteraf besin, sy einde in homself gedra van die begin af. Die skeppingsmatige beperktheid van die mens, wat die modernisme ten alle koste wou oorwin, sou nooit ad infinitum die illusie van absolute waarhede en absolute kontrole kon volhou nie. Histories het die aanspraak op absolute waarhede gelei tot kerklike triomfalisme, ' $n$ onkeerbare reeks van kerkskeurings en 'n pluraliteit of pluralisme van soms sterk botsende absolute waarhede. Teen 1980 was daar alleen in die VSA 2050 verskillende kerke wat uit die Protestante voortgekom het.

In die 19de eeu sou die eerste veranderinge begin uittree. Green (2003:74) sien dit reeds in die triades in die filosofie van Hegel. Jüngel (1983:146v) sien die logiese uiteinde van die Cogitogeïnspireerde absolute waarhede in die denke van Nietzsche: die dood van God is die dood van die God van die modernisme en in feite die aankondiging van die postmodernisme, 'n vernuwing wat egter eers in die 20e eeu filosofies verder gevoer sou word deur Heidegger, Jaspers, Sartre, Wittgenstein, Foucaalt, Lyotard, Derrida, Levinas en andere. Teologies gesproke was die teologiese liberalisme in Europa in die tweede helfte van die 19de eeu alreeds ' $n$ duidelike simptoom daarvan. Dit sou egter eers met die optrede van Karl Barth ' $\mathrm{n}$ antwoord vind in wat soms die neo-ortodoksie genoem word (Green 2003:97-104). In sy Römerbrief breek hy met beide Cogito-denke en die liberalisme op 'n wyse wat Green ' $n$ antisipasie op die postmodernisme sien. Barth erken beide die histories-kritiese metode én die inspirasie van die Skrif, maar handhaaf ook die wese van die Kierkegaardiaanse geloofsprong, naamlik dat geloof nie op rasionele gronde verdedig kan word nie. Die vertrekpunt vir die teologie is die groot kloof tussen mens en God en die feit dat dit God is wat die inisiatief neem. Daarmee het hy die fondamente van die modernisme, naamlik die ontoteologiese orde en die outonome menslike rede uit die spel geneem en finaal absolute kontrole en magsteologie prysgegee.

\section{EKUMENE EN “SOCIAL GOSPEL”}

Hierdie twee verskynsels aan die begin van die 20ste eeu was eweneens ' $n$ aanduiding dat die era van absolute ewige waarhede bo 
en buite die tyd aan die verbygaan was. Die opkomende ekumeniese beweging, aanvanklik as internasionale sendingkonferensie, het in die teenoorgestelde rigting beweeg as die sig immer voortplantende triomfalisme en skeurings. Die "social gospel” as 'n steeds sterker aandrang daarop dat die evangelie nie net tydlose waarhede vir die individu se saligheid bevat nie, maar ook qua inhoud vra om in die tyd, op aarde, in menslike sosiale strukture verwesenlik te word, het eweneens presies in die teenoorgestelde rigting as die modernisme beweeg.

\section{ETIESE EKSKURS II}

Met name die "social gospel" het daartoe bygedra dat mettertyd oorgegaan is tot die (her)vestiging van die (histories tweede maar logies) derde fase van die teologies-etiese aktiwiteit. Dit was naamlik as onvoldoende ervaar dat die absolute religieuese waarhede en die morele waardes daaraan ontleen slegs in ' $n$ teologiese wetenskapsdiskoers ivoortoringagtig vasgelê word in academia se tydverdryf. Gedurende die 20ste eeu sou die kwessie van geloofwaardigheid steeds sterker word, terwyl die groeiende plurale situasie in die glystroom van die ekumeniese beweging die voorheen vanselfsprekende invloed van enkele hoofstroomkerke sou ondermyn.

Die eis was steeds sterker gehoor én gevoel dat die verkondigde Christelike waardes en moraal óók moes realiseer in die breë daaglikse samelewing van menslike aktiwiteite en strukture. So ' $n$ ontwikkeling was natuurlik nie moontlik voordat mense bewus geword het van die steeds sterkerwordende proses van sekularisasie nie. Nou word gevra dat nuwe standaarde in die samelewing gevestig moet word (vanweë juis die sekulêre toestande sou nie sonder meer van Christelike waardes gepraat kon word nie). Dit sou uitloop op die menseregtebeweging en groepe soos die Moral Rearmament, maar kerke is ook ingesluit onder die groep. Aangesien dit alle mense en gelowe moes akkommodeer het dit in die praktyk gelei tot 'n etiese minimalisme, gemeet aan die finale norm van haalbaarheid op die publieke markplein, sodat naas die akademiese tydverdryf as eerste aktiwiteit daar nou ook 'n sosiale etiese markbedryf ontstaan het.

\section{DIE POST-MODERNISME}

In hierdie gedeelte gaan dit slegs om die aanduiding van bepaalde tendense en temas sonder enige teologiese of filosofiese evaluering daarvan. Daar was dus baie tekens dat die modernisme agterhaal 
was. Dit het tot op hierdie dag egter nie verdwyn nie. Daar is steeds mense wat hulle geloof nie anders kan interpreteer as in evidente, ewige en absolute waarhede nie. In reaksie op die verswakking van die Cogito-model wat sonder meer uitgemaak is as teologiese liberalisme ("alles op losse skroewe") het verskillende behoudende groepe begin werk met wat hulle as "fundamentals" beskryf het, waaronder die letterlike foutloosheid van die Bybel. Die wyse waarop hulle dit gedoen het, het egter eerder bygedra tot ' $n$ afswakking van die gesag van die Bybel, die ware aard van die geloof en die rol van die Heilige Gees. Dit sou in elk geval nie die opmars van die postmodernisme stuit nie.

Die postmodernisme wat van die tweede helfte van die 20ste eeu op gang gekom het, kan losweg beskryf word as 'n korreksie op die modernisme. In die eerste plek is waarheid veelvormig/relatief, want die uitgangspunt is nie meer die suiwer denkende subjek met toegang tot tydlose, ewige absolute waarhede nie. Wat ons weet (die waarheid) is linguïsties en dus kultureel en sosiaal gevorm - die waarheid word nie hier buite gevind nie en indien wel, is dit volledig dekonstrueerbaar. Die sogenaamde universele en objektiewe waarhede van die modernisme is ' $n$ magspel wat een bepaalde standpunt wil verabsoluteer. Hulle oordeel dat ons nie kan dink (wat sê wat praat) sonder taal nie: daar is niks buite die teks (konteks) nie. Daar is nie " $n$ "raw prelinguistic experience" nie. Taal is die voorwaarde vir denke, in feite konstrueer dit die wêreld, waarmee die pluraliteit in opvattings aangedui word, juis as basis vir die dekonstruksie van alle totaliserende narratiewe (metanarratiewe). Vir baie mense sou hierdie "centrelessness" dui op ekstreme individualisme en relativisme.

\section{EN DIE TEOLOGIE?}

Die teologie was nie onberoerd gelaat nie, om dit sagkens te stel. Alle teologie word nou voor die dilemma geplaas: as daar enersyds nie meer absolute waarhede is nie en alle triomfalisme is taboe, wat word dan van ' $\mathrm{n}$ belydenis wat wél triomfantlik absoluutheid en uniekheid opeis, soos "Jesus is die Here”? Is volslae relativisme nie die enigste einde nie?

Daar was wye en uiteenlopende reaksie van die kant van teoloë, met 'n groot verskeidenheid van tiperinge: van radikaal ortodoks en konserwatief, tot dekonstruktief, konstruktief, rekonstruktief, tot nuwe bevrydings- en feministiese teologie, tot post- 
liberaal, post-metafisies, post-krities en post-ontoteologies (Vanhoozer 2003). Die vry algemene gevoel is dat 'n terugkeer na die modernisme ' $n$ onbegaanbare weg is, selfs onder die konserwatiewes. Dit loop saam met enersyds ' $n$ duidelike afswakking van die liberalisme in die teologie en andersyds die oortuiging dat daar in die postmodernisme positiewe perspektiewe aanwesig is wat met ' $n$ "nuwe" teologiese rigting versoenbaar is (vgl die bydraes van Moltmann, Lindbeck, Jenson, Jüngel, Grenz, Frei, Hauerwas, Volf - om maar net ' $n$ paar van die bekendes te noem). Graham Ward (2003: 76) wys daarop dat post-liberale en konserwatiewe teoloë veral gebruik maak van die later werke van Derrida. Sy beskrywing van die postmoderniteit as " $n$ geleentheid vir die "return of the depressed", met name die "ander" wat deur die magsteologie van die modernisme uitgesluit was, word gesien ook as die terugkeer van godsdiens en teologie as ' $n$ metadiskoers (Vanhoozer 2003:21), nie langer in die vorm van die modernistiese wetenskap nie, maar as ' $n$ religieuse diskoers wat die profetiese en die mistieke insluit, eintlik meer ' $n$ teodrama as ' $n$ teologie omdat die mens nou gesitueer word binne die narratief van Gods skeppende en verlossende handelinge. Sommige teoloë vind dat Derrida se denke oor iets "beyond" dekonstruksie, in die naam waarvan dekonstruksie plaasvind, naamlik geregtigheid, en dat die rol wat gawe (gift) in sy denke speel, ' $n$ messiaanse wending is wat dui op die perspektief van hoop in die postmodernisme. So is daar ook die opvallende ooreenkoms tussen die Christelike eis van "onvoorwaardelike respek vir die mens" en Levinas se "infinite respect for the irreplaceable other" (Vanhoozer 2003:16).

Die merkwaardige is nou ook die herontdekking van die waardevolle fasette van die pre-moderne denke en geloofstaal. Soms ervaar ' $n$ mens die gevoel dat daar tussen pre- en postmodern in baie opsigte ' $n$ kontinuïteit is, ' $n$ herstelde kontinuïteit na die onderbreking deur die rasionalistiese intermezzo van die modernisme. Murphy en Kallenberg (Vanhoozer 2003:39) wys veral na die bydraes van Nicholas Lash (Theology on the way to Emmaus 1986) en Yoder (in M Cartwright (red) 1994 The Royal Priesthood, p 37v). Teenoor die modernisme se logiese en analitiese denke wil beide pre- en postmoderne denke eerder ' $n$ kwalitatief ander soort "persuasion" gebruik. Daar is egter geen sprake van 'n eenvoudige terugkeer nie - histories en teologies is dit onmoontlik. Dit gaan eerder om die tot spraak bring, of tot bewussyn bring, van outentieke 
Christelike geloofstaal en -besit wat so lank gesluimer het. Hieronder is veral belangrik die waarheidsbegrip, die rol van die Heilige Gees, die geloofsnarratief, die geloofsgemeenskap, die rol van doksologie en die rol van apokaliptiek.

Teenoor die premoderne voorstelling of verstaan van die waarheid as veelvormig en verskillend van gestalte na aanleiding van die verskillende grondvorme van religieuse spreke (vgl die descensus) het die modernistiese dogmatiek die rasioneel-logiese vorm van spreke en waarheid as bykans die enigste grondvorm hanteer in die strewe na absolute en ewige waarhede en die mag en die kontrole wat dit skynbaar gebied het.

Verre daarvan dat in die postmodernisme nou ' $n$ ekstreme relativisme aanvaar word, is die betrokke teoloë terdeë daarvan bewus dat elke teologie ' $n$ voluit menslike onderneming is en dat die veelheid van teologieë te make het met die feit dat met verskillende paradigmas of lense gewerk word, dat elke teologie gevorm word deur bepaalde linguistiese en simboliese grondvorme. Lindbeck (wat erkenning gee aan Derrida se denke) handhaaf dat taal voorafgaan aan denke en dit struktureer sodat geen waarheid losstaan van die taal en kultuur waarbinne dit gevorm is nie (Green 2003:64-69). Die modernistiese kritisisme het juis nie rekening gehou met die mensheid se geonderdompel wees in geskiedenis en taal nie (Frei). Niemand beskik oor 'n "God's-eye point of view" nie. Geen wetenskap kan ons losmaak van ons "horison" (Gadamer) nie. Geen teologie kan ons die absolute waarheid waarborg nie. Lindbeck (Green 2003:64-69) probeer die konsekwensie van radikale relativisme ontloop deur anders as Derrida 'n singewende en ander voorafgaande spreke, nl. die spreke van God (In die begin was die Woord .... Joh 1:1) te erken. Die debat herinner aan A E Loen se De Vaste Grond. Dis 'n spreke wat aan alle taal, denke en waarheidsbegrippe voorafgaan. Verskillende teoloë begin nou in hierdie sin weer kyk na fasette van die premoderne voorstellinge en in hierdie verband is dit veral die wyse waarop die voorafgaande spreke van God in die premoderne Christendom as geïnkarneerde Woord gehandhaaf is sonder ' $n$ ontoteologiese Cogito-sisteem. Hiermee loop parallel die voortgaande spreke van God deur Skrif en credo wat so die outentieke oord van die waarheid, losgewikkel uit die rasionalistiese magsgreep van die outonome subjek, weer aandui en herstel.

Hieruit volg verskeie belangrike sake. Die luister na die waarheid in Skrif en credo help ons om tog ons onderlinge familie- 
trekke (Green 2003:68) te herken, en, soos familie, hierdie eenheid te probeer bewaar ten spyte van onderlinge verskille. Dit is basies in die teenoorgestelde rigting aan die eindelose kerkskeuring, naamlik ekumene. Tweedens maak dit duidelik dat nie slegs die outentieke oord van die waarheid verskil van die modernisme nie, maar ook die aard daarvan. Die waarheid as geïnkarneerde Woord is naamlik nie die gevolg van ' $n$ rasionele denkproses nie, maar eerder die gevolg van ontmoeting en relasie. Want die waarheid is in die eerste plek persoonlik - 'n persoon wat nie net in die preek beskryf word nie, maar ontmoet word in liturgie, sang, gebed en sakrament (Green 2003:94). In dié sin is die heilsgeskiedenis nie afgehandel nie, maar gaan in diens aan die Waarheid steeds verder, soos dit inderdaad by die vroeë kerkvaders aangetref word.

Dit is hierdie verhaal wat in die geloofsnarratief steeds verder voortgedra word en daarom was dit eintlik te verwagte dat die huidige besinning sou uitkom by die herontdek van die narratief as waarheidsmedium. Hierdie narratief verskil van rasionalistiese metanarratief wat in die laaste instansie maar net 'n menslike magsmiddel was in die kleed van die Christelike godsdiens. Die geloofsnarratief ontspring nie in die tetiese werk van die outonome rede nie, maar in die geloofsakte van 'n belydende gemeenskap wat oortuig is deur die storie van die geïnkarneerde Woord - nie 'n selfgemaakte narratief nie, maar ' $n$ geskenkte een. Tweedens, die herstel van die Bybelse narratief, met name in die geïnkarneerde Woord en die daaruit vloeiende gesagsvolle getuienis in die kanon en credo moet in die nouste verband met die werk van die Heilige Gees gesien word. Die modernistiese kennisideaal het prakties die Heilige Gees op non-aktief gestel, iets waarvan die grootskaalse uittog van charismatiese en pinkstergroepe naas die geykte verklarings inderdaad getuienis lewer. Juis nou is daar ' $n$ sterk behoefte aan die herstel van die rol van die Heilige Gees, nie alleen in die korrekte verstaan van kanon en credo nie, maar óók in die eksistensieel word van die Woord wat deur die Gees elke môre weer nuut is. Derdens groei die oortuiging dat ons narratief, die lewend hou van ons tradisie, wat nie ' $n$ keuse is nie, maar doodgewoon die feit van ons verbondenheid met die verlede, dat dit alleen ' $n$ ware narratief is as dit die hele geskiedenis insluit, die goeie en die slegte, premodern, modern en postmodern. Geen feit of fase is irrelevant nie. Dit is miskien die basiese fout van die postmoderne teologie van Hick, dat dit die Christelike narratief te radikaal onderbreek. Dit het al begin met die 
ekstreme histories-kritiese metode wat die Skrif self opge-breek het in fragmente wat elk in terme van iets anders as die Bybelse narratief verklaar word (Frei: The Eclipse of Biblical narrative, vgl Vanhoozer 2003:151). Ons bly verbonde aan ons verlede, ons "horison" en volledige afhanklikheid van ons tradisie wat die "socially embodied argument" is vir die beste verstaan van ons gesagvolle teks (Alasdair MacIntyre) en die rasionaliteit daarvan is onomkeerbaar altyd ' $n$ "tradition-based rationality”. Wat Thomas Kuhn (1970) gesê het van die wetenskap, naamlik dat die primêre faktor in die verstaan van die wetenskap nie die wetenskaplike metode is nie maar die "scientific community", geld ook hier ten opsigte van die "socially embodied argument" van die tradisie.

Dit plaas opnuut die Christelike geloofsgemeenskap in die kollig. Dit is naamlik die moederbedding waarin die narratief vloei wat ons identiteit bemiddel. Die eenvoudige subjek-objek skema word in die narratiefdraende gemeenskap oorskry in die sin dat beide teks en leser objekte word van die interpreterende gemeenskap in lewende en partisiperende intersubjektiwiteit (Vanhoozer 2003:154).

Die lewende Woord spreek in die geloofsgemeenskap deur die Bybel in ' $n$ realistiese narratief waarin kruis en opstanding in ' $n$ finale sin "the really real" (Lindbeck) definieer as die volheid van God se identiteit: Jesus is die Here. Dit is wat die lewende Woord ook kommunikeer deur Credo, aanbidding, lied en verkondiging, nie as ' $n$ eenmaal geformuleerde abstrakte beginselteologie nie (so ' $n$ teologie het altyd die neiging om die Skrif te verplaas), maar as ' $n$ lewende proses waardeur jou eie wêreld steeds dieper ingetrek word in verskillende lae van die teks se betekenis (Dit is natuurlik ' $n$ verrassing om te ontdek dat die proses ook 'n ekumeniese beweging is). Teenoor die Westerse individualisme en sosiale atomisme het die begrip van gemeenskap en verhoudinge die afgelope tyd groot prominensie ontvang (Grenz 2003:252v).

Die (her)ontdekking van die koinonia het nie net te make met ' $n$ alternatiewe sosiale werklikheid teenoor die ekstreme individualisme nie, hoewel dit op sigself al belangrik is. Grenz beklemtoon dat die betekenis van die lewe nie individueel nie maar gemeenskaplik ervaar word - die self is immers 'n sosiale produk. Webster (2003:219v) oordeel dat die naaste gegee is as eis tot gemeenskap en ten diepste wortel dit in God se gemeenskap met sy skepping. Daar is nie werklik sprake van ' $\mathrm{n}$ persoon buite relasies nie, net so min as wat hy/sy ' $n$ persoon buite die narratief is (MacIntyre soos aangehaal 
deur Webster). Mense is voor alles storievertellers: juis jou storie gee sin, en in die gemeenskap deel almal ten slotte in die gemeenskapsnarratief. Identiteit is nie bloot privaat nie maar kommunaal. Verhey (2003:98) beklemtoon dat die mens ' $n$ "embodied and communal self" is: die gemeenskapsnarratief verbind die verlede aan die toekoms as 'n "community of memory and hope" (Grenz 2003:255).

Daarom speel die geloofsgemeenskap ' $\mathrm{n}$ kardinale rol in die siening van waarheid. Waarheid (en dus gesag) setel nie in die individuele subjek se bewussyn nie, maar in die gemeenskapsbewussyn van die interpreterende gemeenskap wat die Skrif onder leiding van die Gees as die gesaghebbende paradigmatiese interpretatiewe raamwerk (Lindbeck se formulering) gebruik om die self en die wêreld te verstaan. "Scripture can only be rightly understood from within the believing community" (Vanhoozer 2003:161). En dit geld ook van geloof self: die Christelike geloof self kan slegs werklik binne die geloofsgemeenskap verstaan word. Hauerwas druk dit nog sterker uit: om die Skrif reg te verstaan moet ons geoefen wees in die Christelike deugde wat slegs in die gemeenskap kan gebeur (by Vanhoozer 2003:161). Green brei hierop uit met verwysing na Ricoeur: die praktyk en oefening in die Christelike geloof in die geloofsgemeenskap gaan vooraf aan groei in geloof en kennis, dir wil sê betrokkenheid in die geloofsgemeenskap staan voorop (Green 2003:185v), waardeur kennis en geloof (vertroue) holisties gedefinieer word (HK vraag 21).

\section{ETIESE EKSKURS III}

Met bogenoemde ontwikkeling word die (logies) tweede teologiesetiese aktiwiteit duidelik. Is die eerste, naamlik die akademieswetenskaplike diskoers gerig op die identifisering van waardes en norme dan is hierdie aktiwiteit, naamlik die pastorale gemeenskapsdiskoers (prediking, storie, tradisie, onderrig) gerig op die konkretisering van die waardes as deugde en karakter. Is die gevaar van die eerste ' $n$ onskadelike tydverdryf, dan is die gevaar van die tweede ' $n$ geïsoleerde tuisbedryf. Om dit te voorkom moet dit ook in die sosiaal-maatskaplike werklikheid binnedring, weliswaar dan in die erg verwaterde en eties-minimalistiese vorm van haalbare sosiale standaarde (die wese van 'n markbedryf). Belangrik is die feit dat dit ' $n$ eties-hermeneutiese sirkel vorm met ' $n$ voortdurende beweging tussen die drie aktiwiteite waarby die swaartepunt in die funksie van die Christelike gemeenskap geleë is. 
Binne die gemeenskap is alle teologie "God-talk" en daarom is dit ook die spreke oor alle dinge sub specie divinitatis en trinitaries, in die besonder dan pneumatologies (return of the depressed!). Die Heilige Gees se werk is die kerk of geloofsgemeenskap en moenie al te "geestelik" opgevat word nie. Die herstel van Skrif en tradisie is om deel te hê aan die werk van die Gees wat juis die gemeenskap se gebruike of "practices" vorm: liturgie, gebede, sakramente ens. Dit is juis deur hierdie "practices" dat die verlede en die toekoms bymekaar gebring word en 'n hegte solidariteit geskep word. Die mens se begin was in ' $n$ tuin, maar sy finale toekoms is ' $n$ stad waar God by hulle woon en op pad daarheen werk die Gees immer gemeenskapstigend. Die kenmerke van die kerk word so in die aktiewe vertaal: een word verenigend, heilig word heiligend, algemeen word versoenend, apostolies word verkondigend.

Dit is die wyse waarop Skrifverstaan verdiep word om die betekenisgelaagdheid, veelkleurigheid en veelfasettigheid daarvan te ontgin. Lindbeck beskryf die uitkoms van 'n gelowige luister na die lewende Woord as iets wat meermale ' $\mathrm{n}$ complexio oppositorum van betekenisse (by Green 2003:147) bevat, maar dan as ' $n$ veelheid wat die verskillende dimensies van dieselfde realiteit aandui. Ons het gesien dat die voorkoms van verskillende grondvorme van godsdienstige taal juis gedui het op betekenisgelaagdheid, maar ook dat dit iets wat reeds in die teks van die Bybel aanwesig is, en die ontsluiting van die onveranderlike, "selfauthenticating" en geloofwaardige teks en gelaagdheid word deur die Gees in bepaalde tye en kulture belig. Miroslav Volf (by Green 2003:104v) wys daarop dat geloof nie slegs semioties oorgedra word nie, maar ook nie-semioties. Dit open naas die gelaagdheid ook die oog vir mistiek. Voorbeelde: Romeine 1:17 (regverdiging deur die geloof alleen) was wel van die begin af in die Bybel, maar sou eers 16 eeue later in ' $n$ dieper betekenislaag onthul word. Die Skrif het altyd in homself ' $n$ bepaalde mensbeeld gedra, maar dit sou 19 eeue duur vir slawe en 20 eeue vir vroue voordat ' $n$ beslissende betekenislaag van die mensebeeld na die oppervlak gekom het. Genesis 2:15 (die opdrag om die tuin te bewerk en op te pas) was eweneens altyd maar daar. Dit was egter eers onder die dreigende ekologiese krisis van die afgelope vyftig jaar dat mense begin het om dit raak te lees. In ' $n$ korte 25 jaar sou die NG Kerk se lees van die Bybel opeenvolgend apartheid goedkeur, dit tolereer en dit verwerp. In die jongste verlede het ons gesien hoe die groei in die lees van die Bybel gelei het tot 
versoenende houdings in die resente verhouding tussen Lutherane en Rooms-Katolieke - na meer as vier eeue.

Dit is heel gepas dat in die verskeidenheid van huidige ontwikkelinge die "return of the depressed" ook die doksologie insluit. Miskien is dit ingelui met Jean Luc Marion se God without Being van 1991, 'n boek gemik op die bevryding van God van ' $n$ bepaaldheid deur denke en taal, veral synsdenke. Om God voor te stel as die Hoogste Syn is konseptuele afgodery, aangesien hierdie Godsbeskrywing maar net die spieelbeeld is van menslike denke, die God van die filosowe, maar nie van Abraham, Isak en Jakob nie. Konseptuele denke, beide katafaties en apofaties kan nie die lewende God skep nie. Ons kom net nader na God deur Hom lief te hê (religieus-liturgies) in ' $n$ doksologie wat nie positief of negatief oor God dink nie maar slegs resloos na Hom uitreik. Deurgedink bring die voorafgaande ontwikkelinge ons weer dig in die beurt van vraag 21 van die Heidelbergse Kategismus en word dit onvermydelik dat ons ' $n$ baie meer holistiese siening van kennis en vertroue sal hê. Die storie van geloof en teologie, met die huidige klem op die veelheid van grondvorme, die gestaltes en gelaagdheid van die waarheid gaan inderdaad terug tot in die vroeë Christendom. Die opvallende aansluitingspunte tussen pre- en postmodern veral ten opsigte van die doksologie bring ook die interessante saak van die apokaliptiek na vore. Aulén, soos ons gesien het, oordeel dat dit die klassieke en mees outentieke versoeningsvoorstelling is. Onlangs het Walter Lowe (2003:235v) gevra vir die herinvoering van die apokaliptiese motief in die Christelike denke in die lig van die wêreldwye stryd vir geregtigheid en teen armoede. ' $n$ Mens moet erken dat die onvoorspelbare morele en sedelike depravasie, oorloë en natuurrampe (veral mensgemaak) op sig al so 'n scenario skep. Lowe verwys na die Galasiërkommentaar van J Louis Martyn wat dit as 'n spesifiek apokaliptiese brief sien (die ganse tyd en geskiedenis word binne in die Christusgebeure geplaas). Vanhoozer (2003:24) verwys na Mary Midgley se uitspraak: "The devolution of Wisdom into Knowledge into Information may be the supreme source of degeneration in the postmodern society". ' $n$ Mens dink ook aan Luther se hantering van die apokaliptiek, veral ook as die oord vir doksologie. 'n Sterk saak word ook uitgemaak deur C E Braaten (2002:14v) in wat hy noem: The Recovery of Apocalyptic Imagination. 


\section{TEN SLOTTE}

Johan Heyns se dogmatiek verskyn in 1978, en Lyotard se The Postmodern Condition eers in 1979. Tog is daar genoeg aanduidings in sy werk om te konkludeer dat Johan Heyns teologie ' $n$ hele ent verder help bring het. In die lig van die inhoud van hierdie artikel kan ons slegs verwys na sy Skrifbeskouing, sy opvatting van die semper reformanda-idee, die ekumene, die progressie in uitsprake (die kerk), sy onderskeiding van waarheidsgestaltes (bv logies en eties) en die praktiese betekenis van die geloof (drie volumes etiek). Dit behoort tot die verliese van gereformeerde teologie dat hy nie verder hieraan kon meedoen nie. Ons is opreg dankbaar vir die groot rol wat hy nietemin kon speel en sal voortgaan om te speel deur die denke van sy studente en kollegas.

\section{Literatuurverwysings}

Altaner, B \& A Stribe 1966. Patrologie. Leben, Schriften und Lehre der Kirchenväter. Freiburg: Herder.

Aulén, G 1969. Christus Victor. An historical study of the three main types of the idea of atonement (die vertaling van A G Herbert van 1931). New York: Macmillan Publishing Co.

Braaten C E \& R W Jenson (eds.) 2002. The Last Things. Biblical and Theological Perspectives on Escathology. Grand Rapids: W Eerdmans Publishing Company.

Du Toit, D A. 1971. "neergedaal ter helle". Uit die geskiedenis van ' $n$ interpretasieprobleem. Kampen: JH Kok, NV.

Frei, H W 1974. The Eclipse of Biblical Narrative. A study in Eighteenth and Nineteenth Century Hermeneutics. New Haven \& London: Yale University Press.

Green, R C 2003. Mapping postmodernism. A survey of Christian options. Downers Grove: Intervarsity Press.

Grenz, S J. Ecclesiology, in K Vanhoozer (ed) 2003 Cambridge Companion to Postmodern Theology, Cambridge University Press, 252-268.

Jüngel, E 1983. God as the Mystery of the World. On the foundation of the Theology of the Crucified One in the Dispute between Theism and Atheism. Edinburgh: T\&T Clark Ltd.

Kuhn, T S 1970. The Structure of Scientific Revolutions. University of Chicago Press.

Lowe, W. Christ and Salvation, in K Vanhoozer (ed) 2003, Cambridge Companion to Postmodern Theology, Cambridge University Press, 235251. 
Moltmann, J 1993. Theology of Hope. On the ground and the implications of a Christian Eschatology. Minneapolis: Fortress Press - SCM 1967).

Schlink, E 1961. Den Kommende Christus und die Kirchliche Traditionen. Beiträge zum Gespräch zwischen den getrennten Kirchen. Göttingen: Vandenhoeck \& Ruprecht.

Tracy, D 1994. On naming the present. Reflections on God, Hermeneutics and church. Maryknoll: Orbis Books.

Vanhoozer, K J 2003. The Cambridge Companion to Postmodern theology. Cambridge University Press.

Verhey, A 2003. Reading the Bible in the strange world of medicine. Grand Rapids: William B Eerdmans.

Ward, G. Deconstructive Theology, in K J Vanhoozer (ed) 2003. The Cambridge Companion to postmodern Theology. Cmabridge University Press.

Webster, J. The Human Person, in K Vanhoozer (ed), 2003. The Cambridge Companion to postmodern Theology, Cambridge, University Press. 